\title{
PENILAIAN PEDOFILIA MENGGUNAKAN RESPON HEMODINAMIK OTAK TERHADAP STIMULI SEKSUAL
}

\author{
Kuhelan Mahendran \\ Program Studi Pendidikan Dokter, Fakultas Kedokteran Universitas Udayana \\ (kuhelan91@gmail.com)
}

\begin{abstract}
ABSTRAK
Menilai secara akurat orientasi seksual seseorang sangat penting dalam melakukan penanganan terhadap pelaku kekerasan seksual pada anak. Phallometry adalah metode standar untuk mengidentifikasi orientasi seksual; tetapi, metode ini telah banyak dikritik oleh karena bersifat intrusif dan reliabilitasnya terbatas.
\end{abstract}

Tujuan:Untuk mengevaluasi apakah pola respon spasial terhadap stimuli seksual yang ditandai oleh adanya perubahan blood oxygen level-dependent signal (BOLD)memfasilitasi proses identifikasi pedofilia.

Desain:Selama dilakukan pemeriksaan magnetic resonance imaging fungsional (fMRI), ditampilkan gambar anak-anak dan dewasa tanpa busana dengan jenis kelamin sama atau berbeda terhadap sampel penelitian (kelompok pedofil dan kontrol). Kami mengkalkulasi perbedaan BOLDterhadap stimuli sexual anak-anak dan dewasa pada setiap sampel. Hasil foto dengan kontras kemudian dimasukkan sesuai dengan kelompoknya untuk dianalisis perbedaan pemetaan otak antara kelompok pedofil dan kontrol. Kami mengkalkulasi nilai ekspresi yang sesuai dengan hasil kelompok bagi setiap sampel. Nilai ekspresi tersebut dibedakan menjadi 2 algoritma klasifikasi: analisis Fisher linear discriminant dan analisis $\kappa$ nearest neighbor. Prosedur klasifikasi tersebut telah divalidasi silang menggunakan metode leave-oneout.

Lokasi:Bagian Kedokteran Seksual, Fakultas Kedokteran Universitas Christian Albrechts di Kiel, Jerman.

Sampel:Kami merekrut 24 sampel dengan pedofil yang memiliki ketertarikan seksual terhadap anak perempuan $(n=11)$ atau laki-laki $(n=13)$ pre pubertas dan 32 kontrol laki-laki sehat yang memiliki ketertarikan seksual terhadap wanita $(n=18)$ atau pria $(n=14)$ dewasa.

Pengukuran luaran utama:Angka sensitivitasdan spesifisitas dari kedua algoritme klasifikasi.

Hasil:Akurasi klasifikasi tertinggi dicapai dengan analisis diskriminan linear Fisher, yang menunjukkan akurasi rata-rata $95 \%$ (100\% spesifisitas, $88 \%$ sensitivitas).

Simpulan:Pola respon otak fungsional terhadap stimuli seksual mengandung informasi yang cukup untuk mengidentifikasi pedofilia dengan akurasi tinggi. Klasifikasi otomatis dari pola tersebut merupakan alat ukur objektif yang menjanjikan untuk mendiagnosis pedofilia secara klinis.

\section{PENDAHULUAN}

Berdasarkan investigasi retrospektif yang dilakukan di Jerman, 8,6\% wanita dewasa dan 2,8\% laki-laki dewasa dilaporkan bahwa mereka pernah menjadi korban kekerasan seksual di bawah umur. Karena tingginya insiden kekerasan seksual tersebut, banyak penelitian telah dilakukan untuk mengetahui penyebab kekerasan seksual pada anak, mengembangkan terapi yang efektif terhadap pelaku kekerasan seksual, mengembangkan metode yang efektif untuk memprediksi kekambuhan.

Pertama, penelitian pada area ini harus mempertimbangkan bahwa beberapa pelaku kekerasan seksual adalah pedofil dan yang lainnya tidak. Penilaian phallometricterhadap pelaku korban tunggal menunjukkan bahwa sekitar setengah dari 
mereka adalah pedofil. Berdasarkan kriteria diagnosis terbaru, orang dengan pedofil mengalami ketertarikan seksual yang menetap terhadap anakanak pre pubertas dan pernah bertindak menuruti dorongan seksual tersebut atau merasa tertekan karenanya (DSM-IV-TR kode 302.2). Meskipun etiologi dari kekerasan anak-anak baik oleh pelaku pedofil maupun non pedofil belum dipahami sepenuhnya, penelitian dari beberapa area yang berbeda menunjukkan bahwa terdapat faktor sosial dan neurodevelopmental. Terlebih, pemeriksaan MRI morphometric menemukan volume gray matter pada amigdala dan area lainnya yang berhubungan seperti hipotalamus, ventral striatum, korteks orbitofrontalis, dan serebelum, begitu pula penurunan volume white matter pada fasikulus fronto-oksipital superior dan fasikulus arkuata kanan. Tetapi, perubahan struktural tersebut hanya menunjukkan sedikit kesamaan karakteristik pada beberapa penelitian.

Orang dengan pedofilia menunjukkan penurunan respon neural terhadap rangsangan erotis dewasa pada area otak yang terlibat dalam pemrosesan rangsangan seksual, misalnya amigdala, hipotalamus, dan korteks prefrontalis pada studi MRI fungsional. Paparan terhadap rangsangan seksual yang sesuai dengan orientasi seksual mereka (yaitu gambar anak-anak tanpa busana), sebaliknya memunculkan aktivasi spesifik terhadap orientasi seksualnya mirip dengan keadaan yang muncul pada orang dewasa dengan orientasi seksual yang sehat. Pada satu penelitian dilaporkan suatu hipoaktivasi korteks orbitofrontalis dan hiperaktivasi korteks prefrontalis dorsolateral; bukti tersebut diinterpretasikan sebagai disfungsi pemrosesan rangsang sekxual pada jaringan prefrontal.

Meskipun tidak ada bukti yang konsisten mengenai profil aktivasi abnormal pada pedofil, perubahan pola aktivasi spesifik terhadap orientasi seksual yang dimunculkan oleh pemberian rangsang seksual dapat digunakan untuk menilai pedofilia. Dengan menggunakan algoritma klasifikasi otomatis, Ponseti dkk mengetes apakah aktivitas otak sebagai respon terhadap rangsang seksual yang disukai dan yang tidak dapat memprediksi orientasi seksual pada sampel laki-laki dewasa heteroseksual dan homoseksual sehat. Mereka menemukan bahwa akurasi rata-rata dari algoritma klasifikasi tersebut melebihi $85 \%$, yang mana mengindikasikan bahwa pola respon fungsional otak terhadap rangsang seksual mengandung informasi yang cukup untuk memprediksi orientasi seksual seseorang dengan akurasi yang tinggi. Beberapa penelitian lain yang juga meneliti tentang metode efektif dalam penilaian penyakit-penyakit neurologis dan psikiatri yaitu penggunaan teknik klasifikasi otomatis pada hasil pemeriksaan MRI otak utuh. Sebagai contoh yaitu akurasi klasifikasi di atas $85 \%$ telah dicapai menggunakan MRI otak struktural pada pasien dengan penyakit Alzheimer dini, gangguan obsesif kompulsif, dan psikosis prodromal atau penggunaan MRI fungsional pada pasien dengan depresi mayor.

Penilaian terhadap adanya orientasi seksual parafilik mempunyai peran penting dalam memprediksi kekambuhan. Terlebih lagi, terapi efektif terhadap pelaku kekerasan seksual pada anak bergantung pada penilaian yang akurat terhadap orientasi seksual parafilik, mengingat beberapa intervensi medis sesuai untuk pelaku kekerasan seksual pedofilik tetapi tidak untuk yang non pedofilik dan begitu pula sebaliknya. Pada kasus-kasus dimana tidak adanya catatan forensik dan laporan yang meyakinkan (misalnya kekerasan seksual yang pertama kali), penilaian yang valid terhadap orientasi seksual hanya dapat dilakukan dengan menggunakan pengukuran phallometric, standar terkini untuk menilai penyimpangan seksual secara objektif. Selama pengukuran phallometric, sampel diminta untuk memasang suatu alat melingkari penisnya untuk mencatat respon erektilnya. Phallometry telah dikritik tidak hanya oleh karena bersifat intrusif tetapi juga terdapat proporsi ketiaadaan respon yang tinggi. Berdasarkan survey laboratorium, hasil tes phallometry yang ditolak oleh karena respon yang rendah (yang pada umumnya dianggap sebagai variasi random) mencapai $40 \%$. Proporsi ketiadaan respon dapat diturunkan sampai mendekati $2 \%$ menggunakan volumetric phallometry, penilaian terhadap respon penis yang lebih sensitif dan akurat. Tetapi, sebagian besar 
laboratorium masih menggunakan pengukuran phallometricyang mengukur panjang keliling (sirkumferensial) karena penggunaannya yang lebih mudah dibandingkan dengan pengukuran volumetric phallometry.

Penelitian ini memeriksa apakah klasifikasi pola pada data fMRI secara otomatis dapat memprediksi orientasi seksual parafilik. Kami mengetesnya menggunakan metode klasifikasi parametrik (Fisher linear discriminant analysis) dan non parametrik ( $\kappa-$ nearest neighbor analysis). Kami berhipotesis bahwa peta yang menggambarkan perbedaan regional pada level ketergantungan terhadap kadar oksigen dalam darah sebagai respon terhadap rangsangan seksual seharusnya dapat mengindikasikan orientasi seksual seseorang.

\section{METODE}

\section{Sampel}

Kami merekrut 25 sampel laki-laki yang masuk dalam kriteria diagnosis pedofil sesuai dengan DSM-IV-R3 (tipe eksklusif dan noneksklusif) dari 2 klinik Kesehatan Seksual rawat jalan yang tergabung dalam proyek preventif Dunkelfeld, yang menawarkan terapi untuk kasus pedofil yang dilaporkan sendiri. Prosedur inklusi standar dari proyek preventif Dunkelfeld yang meliputi wawancara medis dan kuisioner untuk mengukur minat seksual, perilaku, dan konsumsi pornografi anak, ditujukan untuk menilai minat pedofilia. Kami mengeksklusi 1 sampel karena pada analisis yang lebih jauh, ditemukan hasil pemeriksaan terhadap rangsang seksual sebelumnya menunjukkan kesukaannya terhadap wanita dewasa. Berdasarkan laporan sukarela, 11 dari sisa sampel dengan pedofil memiliki ketertarikan seksual terhadap anak perempuan pre pubertas (pedofil heteroseksual) dan 13 lainnya tertarik pada anak laki-laki pre pubertas (pedofil homoseksual). Orientasi seksual dipastikan dengan menggunakan Kinsey rating pada imajinasi ( 0 dan 1 ) dan perilaku (5 dan 6).

Berdasarkan wawancara terstruktur, kami memverifikasi bahwa sampel tidak memiliki klaustrofobia, implan atau komponen metal lainnya di dalam tubuh mereka, riwayat cedera kepala, disfungsi seksual, gangguan identitas kelamin, penyalahgunaan zat selama tahun terakhir, atau pengobatan lainnya yang berkaitan dengan fungsi seksual. Sebagai tambahan, kami mengeksklusi sampel kontrol yang memiliki riwayat parafilia atau tindakan kekerasan seksual sebelumnya. Enam sampel dengan pedofilia dan 2 relawan adalah kidal.

Sampel dikelompokkan berdasarkan umur (rata-rata [SD], pedofilia heteroseksual, 37 [5,9] tahun [rentang 25-46 tahun'; pedofilia homoseksual 33,5 [14,2] tahun [rentang 18-64 tahun]; teleiofil heteroseksual $32,4[8,2]$ tahun [rentang 22-49 tahun]; teleiofil homoseksual, 28.6 [5.7] tahun [rentang, 23-42 tahun]; $F 3,52=1.81 ; P=.16)$ dan intelegensi diukur dengan the Wechsler Adult Intelligence Scale reasoning subtest matrix32 (rata-rata [SD], pedofil heteroseksual, 11 [3.1] skor berskala [rentang,5-16 skor berskala]; pedofil homoseksual, 10.2 [2.9] skor berskala [rentang, 4-14 skor berskala]; teleiofil heteroseksual, 11.8 [2.3] skor berskala [rentang, 515 skor berskala]; teleiofil homoseksual, 11.8 [2 ] skor berskala [rentang, 8-14 skor berskala]; $F 3,52=1.25 ; \quad P=.30)$. Seluruh sampel memberikan persetujuan tertulis sebelum berpartisipasi dalam penelitian ini. Komite etika lokal dari Fakultas Kedokteran Universitas Christian-Albrechts menyetujui penelitian ini.

\section{Perangsangan dan Prosedurnya}

Kami menampilkan 14 kategori gambar yang berbeda selama sesi fMRI, yaitu gambar orang dewasa dan anak-anak tanpa busana (baik gambar seluruh badan tampak depan, hanya alat kelamin, atau hanya wajah) dan gambar non seksual dengan skor yang tinggi maupun rendah sesuai dengan skor dari International Affective Picture System. Pada setiap gambar seksual, hanya 1 orang (atau 1 alat kelamin) yang terlihat tanpa konteks tambahan. Kebalikan dari rangsangan anak-anak, banyak rangsangan dewasa menampilkan tanda-tanda rangsangan pada alat kelamin. Kami menggunakan jenis rangsangan seksual inti tersebut karena penelitian telah menemukan bahwa jenis rangsangan tersebut sangat selektif dalam memicu respon saraf sesuai dengan ketertarikan seksual dari orang yang melihatnya. Kami menampilkan 35 
gambar dari masing-masing kategori dari total 490 gambar. Tetapi, untuk tujuan klasifikasi pola, hanya percobaan dengan menggunakan gambar seluruh badan tampak depan atau alat kelamin saja yang dianalisis. Total digunakan 70 gambar (35 gambar seluruh badan + 35 gambar alat kelamin) masingmasing untuk anak laki-laki, anak perempuan, lakilaki dan wanita dewasa (sehingga terdapat total 280 percobaan pada analisis).

Kami menampilkan setiap gambar selama 1 detik dengan variabel interval antar stimulus (rentang 1-5 detik) pada urutan pseudorandom. Sampel diinstruksikan untuk melihat setiap stimulus secara seksama. Untuk memastikan bahwa sampel memberikan perhatian terhadap stimus, mereka merespon secara manual ketika stimulus oddball (lingkaran hijau) terlihat pada layar. Oddball tersebut ditampilkan sebanyak 20 kali selama sesi fMRI. Stimuli tersebut diproyeksikan ke cermin yang dipasang setinggi level kepala. Segera setelahnya sampel memberikan nilai valensi (derajat penarikan hati seseorang) dan tingkat rangsangan menggunakan skala 9-point Self-Assessment Manikin Likert-type. Untuk setiap stimulus seksual, kami mengalikan nilai valensi dan tingkat rangsangan tersebut untuk mendapatkan indeks kombinasi yang sebelumnya kami temukan memiliki korelasi kuat terhadap derajat ketertarikan seksual.

\section{Prosedur Imaging dan Pengolahan Data}

Scanner MRI 3-T seluruh tubuh (Achieva; Philips, Best, the Netherlands) digunakan untuk memeriksa sampel. Pemeriksaan MRI 3 dimensi dengan spoiled gradient echo acquisition dengan eksitasi volume sagital (1x1x1-mm voxels) mendapatkan struktural volume T1 untuk setiap sampel, diikuti dengan 3 pemeriksaan fMRI. Setiap fMRI terdiri dari 325 volume. Pengukuran sinyal BOLD fMRI dilakukan dengan menggunakan urutan echo planar imaging (EPI) dengan waktu pengulangan 2500 milisekon, waktu eko 36,8 milisekon, dan sudut balik $90^{\circ}$. Lapang pandang meliputi keseluruhan otak (38 irisan aksial, ketebalan irisan $3 \mathrm{~mm}$, jarak antar irisan 0,3 $\mathrm{mm}$ ). Kami memperoleh irisan aksial paralel terhadap bidang komisura anterior posterior.
Kami melakukan pemrosesan data pendahuluan dan analisis statistik menggunakan piranti lunak SPM8 pada Matlab 7.7.0 (Mathworks, Natick, Massachusetts). Kami meluruskan gambar EPI sesuai dengan rerata dan normalisasi spasialnya menggunakan template dari Montreal Neurological Institute. Normalisasi spasial dilakukan dengan mengaplikasikan algoritma segmentasi SPM pada gambar T1-weighted untuk memperkirakan parameter transformasi normalisasi spasial nonlinear. Kami kemudian mencocokkan gambar EPI yang telah diluruskan kembali ke gambar T1weighted masing-masing sampel dan menggunakan parameter normalisasi dari langkah segmentasi untuk menulis versi normalisasi dari gambar EPI (2x2x2 mm voxels). Prosedur ini mengoptimalisasi normalisasi spasial menggunakan gambar T1weighted resolusi tinggi untuk menentukan kompleks fungsi normalisasi spasial nonlinear dan menggabungkan koreksi bias untuk mengatasi potensi heterogenitas tingkat kecerahan pada gambar struktural T1-weighted. Akhirnya, gaussian kernel denggan full-width half-maximum $8 \mathrm{~mm}$ menghaluskan secara spasial gambar EPI yang telah dinormalisasi untuk mengurangi perbedaan anatomis pada sampel dan memungkinkan aplikasi teori gaussian random field.

\section{Analisis Statistik dan Klasifikasi Subjek}

Klasifikasi pola otak utuh terhadap aktivitas serebral dilakukan dengan menggunakan algoritme yang sama dengan yang kami gunakan sebelumnya pada sampel lain. Algoritme ini mempunyai 4 tahapan:

Tahap 1(analysis level pertama): kami menspesifikasi model linear umum untuk urutan waktu fMRI pada masing-masing sampel menggunakan regresor terpisah untuk setiap kondisi stimulus (badan anak laki-laki, alat kelamin anak laki-laki, badan laki-laki dewasa, alat kelamin laki-laki dewasa, badan anak perempuan, alat kelamin anak perempuan, badan wanita dewasa, alat kelamin wanita dewasa) dan 6 regresor dengan parameter pergerakan sesuai dengan tahapan pelurusan kembali. Setiap respon terhadap stimulus dipadukan dengan fungsi respon hemodinamik standar. Koefisien regresi untuk semua regresor diestimasi dengan model subjek- 
spesifik efek-tetap. Filter dengan ketelitian tinggi (nilai batas 128 detik) digunakan untuk menghilangkan arus berfrekuensi rendah pada sinyal BOLD. Berdasarkan estimasi model linear umum subjek-spesifik, kami menghitung peta 2t-statistic dengan membandingkan kondisi stimulus (1) gambar anak laki-laki dibandingkan dengan gambar laki-laki dewasa (2) gambar anak perempuan dibandingkan dengan gambar wanita dewasa untuk setiap voxel. Bagi setiap subjek, kami mendapatkan peta $2 \mathrm{t}$ statistik: yang pertama menggambarkan pola spasial dari perbedan regional respon BOLD terhadap rangsang seksual anak laki-laki dibandingkan dengan rangsang seksual laki-laki dewasa dan yang kedua menggambarkan perbedaan regional respon BOLD terhadap rangsang seksual anak perempuan dibandingkan dengan rangsang seksual wanita dewasa pada seluruh area otak.

Tahap 2 (analisis level kedua): kami membangun sebuah desain fleksibel ( 3 cara) dengan estimasi parameter untuk setiap kondisi stimulus $(n=8)$ untuk setiap subjek sebagai faktor stimulus. Dua faktor yang tersisa pada desain ini yaitu kelompok (2 level) dan subjek (56 level) dan sebagai kovariasi yaitu kovariasi umur dan intelegensi. Kovariasi umur dan intelegensi dimasukkan untuk memperbaiki perbedaan terkait umur atau intelegensi dalam grup. Kedua kovariasi tersebut dipusatkan pada nilai rerata global. Faktor subjek ditujukan untuk menangkap setiap variasi terkait subjek yang tidak dimodelkan oleh faktor lainnya (kidal/kinan). Kami kemudian mengkalkulasi peta statistik ( $t$ contrasts) antara kedua grup untuk menghitung perbedaan regional dalam respon BOLD sesuai ketertarikan terhadap anak laki-laki atau laki-laki dewasa dan terhadap anak perempuan atau wanita dewasa antara kelompok pedofil dan relawan sehat.

Tahap 3 (proyeksi peta $t$ ): untuk menilai dan menghitung efek spesifik masing-masing subjek, gambar kontras yang dikalkulasi pada tahap pertama diproyeksikan ke dalam peta yang menggambarkan perbedaan spesifik grup yang ditentukan pada analisis tahap 2. Peta statistik tersebut menggambarkan pola spasial dari perbedaan respon BOLD yang ditampilkan oleh perbandingan antar group. Proyeksi tersebut diimplementasikan dengan menjumlahkan hasil voxel dari gambar kontras spesifik subjek (anak laki-laki<laki-laki dewasa dan anak perempuan<wanita dewasa) yang ditentukan pada analisis tahap pertama dan peta $t$ dari peta perbedaan grup yang ditentukan pada analisis tahap 2. Penjumlahan ini secara matematis menghasilkan produk vektor titik. Prosedur tersebut dilakukan secara tepisah untuk peta perbedaan dari anak lakilaki vs laki-laki dewasa dan anak perempuan vs wanita dewasa. Hasil penjumlahan produk voxel disebut sebagai "nilai ekspresi individual." Ini mewakili derajat dimana otak merespon suatu subjek (yaitu peta perbedaan $t$ statistiknya) cocok dengan rerata respon otak pada satu grup (yaitu peta perbedaan $t$ statistik grup yang didapatkan pada tahap 2). Nilai ekspresi individual yang tinggi, baik negatif atau positif mengindikasikan bahwa terdapat korespondensi yang baik dengan pola perbedaan dalam kelompok. Nilai ekspresi individual sedang mengindikasikan bahwa individu tersebut menampilkan respon otak yang berada antara polapola ekspresi yang ditemukan dalam grup.

Tahap 4 (klasifikasi dan validasi silang): akhirnya, kami mengumpulkan hasil nilai ekspresi individual ( 2 nilai untuk masing-masing subjek) ke dalam 2 algoritma klasifikasi pola yang berbeda: analisis Fisher linear discriminant parametrik dan klasifikasi $\kappa$-nearest neighbor non parametrik (digunakan 7 nearest-neighbor).

Untuk mengkalkulasi kemampuan mengklasifikasi set data yang tidak diketahui sebelumnya, kami memvalidasi silang kedua metode klasifikasi menggunakan metode leave-one-out (yaitu kami mengabaikan 1 proband dari sampel original). Untuk 55 sampel sisanya, kami mengkalkulasi peta perbedaan $t$ statistik baru (tahap 2). Nilai ekspresi individual kemudian dikalkulasi untuk sampel yang diabaikan tersebut (satu untuk perbandingan anak laki-laki<laki-laki dewasa dan satu untuk perbandingan anak perempuan $<$ wanita dewasa; tahap 3). Kemudian, kami mengklasifikasi sampel sesuai dengan nilai tersebut menggunakan Fisher linear discriminant dan $\kappa$-nearest neighbor (tahap 4). Kami melakukan prosedur leave-one-out tersebut 
sebanyk 56 kali untuk mendapatkan semua sampel. Kami menspesifikasi kekuatan prediktif dari prosedur klasifikasi tersebut dengan mengkalkulasi spesifisitas dan sensitivitas. Kami mengkalkulasi sensitivitas spesifisitas rerata dan akurasi klasifikasi rata-rata (jumlah keputusan benar dibagi dengan total keputusan).

Kekuatan prediktif dari nilai ekspresi individual bergantung pada proporsi voxels signifikan vs nonsignifikan pada peta perbedaan $t$ statistik grup, yang dimasukkan ke dalam perhitungan. Sebagai contoh, jika kalkulasi nilai ekspresi individual didasarkan pada peta perbedaan $t$ statistik otak utuh, lebih banyak "noise" yang akan terakumulasi pada nilai ekspresi individual. Sebaliknya, membatasi nilai ekspresi individual pada area signifikan pada peta perbedaan $t$ statistik grup akan menurunkan pengaruh dari noise tersebut. Pada ketiadaan pengalaman sebelumnya dengan nilai ambang statistik pada kasus ini dan efeknya pada akurasi klasifikasi berikutnya, kami mengetes 4 nilai ambang yang berbeda (otak utuh; $t>2, t>3$ dan $t>4$ ). Kemudian kami melakukan tahap 3 dan tahap 4 dan validasi silang berdasarkan ketiga nilai ambang tersebut untuk menentukan efek dari analisis otak utuh dan regio spesifik.

\section{HASIL}

\section{Respon Prilaku}

Rating sesuai dengan ketertarikan seksual sampel (Gambar 1). Analisis pengukuran berulang terhadap variansi menunjukkan efek utama dari tipe stimulus pada grup teleiofil heteroseksual $\left(\mathrm{F}_{3,51}=42,55\right.$; $\mathrm{P}<0.001)$, teleiofil homoseksual $\left(\mathrm{F}_{3,39}=71,83\right.$; $\mathrm{P}<0.001)$, pedofil heteroseksual $\left(\mathrm{F}_{3,30}=26,25\right.$; $\mathrm{P}<0.001)$, dan pedofil homoseksual $\left(\mathrm{F}_{3,36}=22,62\right.$; $\mathrm{P}<0.001)$. Hal yang menarik yaitu pedofil heteroseksual meranking gambar wanita dewasa dan anak perempuan sebagai atraktif secara seksual, dan perbedaan antara rating tersebut tidak signifikan $\left(t_{10}=1,45 ; P=0,18\right)$. Hasil ini sesuai dengan penilaian klinis dari sampel kami yang menunjukkan bahwa pedofil noneksklusif sebelumnya merupakan pedofil heteroseksual.

\section{Klasifikasi Otomatis}

Analisis variansi (tahap 2) menunjukkan perbedaan signifikan pada peta perbedaan individual antara sampel pedofil dan teleiofil pada area otak luas. Ini ditentukan pada kontras anak laki-laki vs laki-laki dewasa dan anak perempuan vs wanita dewasa (Gambar 2 dan Tabel 1). Tetapi, sebagaimana disajikan pada Gambar 2 dan Tabel 1, perbedaan grup lebih luas pada anak laki-laki vs laki-laki dewasa dibandingkan anak perempuan vs wanita dewasa.

Pada setiap sampel, respon otak individu ditandai oleh 2 nilai ekspresi, satu untuk kontras anak perempuan<wanita dewasa dan satu untuk kontras anak laki-laki<laki-laki dewasa. Gambar 3 menunjukkan nilai ekspresi individual berdasarkan peta $t$ otak utuh untuk keseluruhan 56 sampel (bagian A dan B menampilkan nilai ekspresi identik). Nilai ekspresi individual dari mereka yang memiliki ketertarikan seksual terhadap badan perempuan (teleiofil heteroseksual dan pedofil heteroseksual) berbeda kebanyakan pada perbandingan anak perempuan<wanita dewasa (y-axis pada Gambar 3). Sebaliknya, teleiofil homoseksual dan pedofil homoseksual berbeda terutama pada perbandingan anak laki-laki<laki-laki dewasa (x-axis pada Gambar 3).

Kami memasukkan nilai ekspresi individual kedalam analisis klasifikasi pada nilai ekspresi otak keseluruhan. Validasi silang menunjukkan analisis Fisher linear discriminant bekerja lebih baik daripada klasifikasi $\kappa$-nearest neighbor (Tabel 2). Akurasi klasifikasi meningkat dengan meningkatkan nilai ambang $t$. ketika peta perbedaan otak keseluruhan ditampilkan pada $t>4$, Fisher linear discriminant analysis memberikan hasil klasifikasi terbaik. Hanya 3 sampel yang salah diklasifikasi (negatif palsu). Dari 3 pedofil yang salah diklasifikasi, 2 adalah heteroseksual dan 1 homoseksual. Mereka semua merupakan tipe noneksklusif.

\section{DISKUSI}

Sejauh pengetahuan kami, penelitian ini merupakan yang pertama yang mengaplikasikan klasifikasi pola fungsi saraf untuk menilai pedofilia. Bergantung sepenuhnya pada perbedaan antar grup yang terdistribusi secara spasial terhadap respon otak 
fungsional terhadap stimuli seksual, algoritme klasifikasi pola membedakan sampel dengan pedofil dari kontrol sehat dengan akurasi tingkat tinggi. Akurasi klasifikasi sangat kuat ketika mengklasifikasi peta aktivasi fMRI sampel yang belum pernah dilihat sebelumnya.

Kami memilih sampel campuran dari laki-laki heteroseksual dan homoseksual yang tertarik pada dewasa atau anak-anak untuk mengetes akurasi klasifikasi otomatis tanpa mengetahui kondisi sebenarnya apakah pedofil tersebut homoseksual atau heteroseksual. Dengan mengintegrasikan kedua perbandingan (laki-laki anak vs dewasa) dan (perempuan anak vs dewasa), kami dapat mendiskriminasikan sampel teleiofil dari sampel pedofil secara terpecaya (tidak masalah apakah kemudian mereka merupakan pedofil eksklusif atau noneksklusif pedofil, pedofil heteroseksual, atau pedofil homoseksual). Sebagaimana didemonstrasikan pada gambar 3, perbandingan laki-laki anak vs dewasa dapat mendiskriminasi dalam kelompok homoseksual, yang mana tertarik terhadap dewasa dan yang mana tertarik terhadap anak-anak. Sebaliknya, perbbandingan perempuan anak vs dewasa lebih sensitif untuk mendiskriminasikan sampel ke dalam kelompok heteroseksual.

Ketika mengaplikasikan algoritme klasifikasi pola neurofungsional, akurasi diagnostik bergantung pada kekuatan diskriminatif dari respon otak yang terdistribusi secara spasial sebagaimana dipicu oleh rangsangan. Pada penelitian ini, kami menampilkan stimuli seksual inti yang memicu pola respon dengan diskriminatif tinggi pada sampel. Hasil ini konsisten dengan penelitian sebelumnya yang menunjukkan bahwa stimuli seksual inti dapat memicu respon ketertarikan spesifik pada sampel jenis kelamin atau stimulus apapun.

Kami secara konsisten menemukan aktivitas otak spesifik terhadap ketertarikan seksual pada area otak yang telah diset sebelumnya, kebanyakan diketahui berpartisipasi dalam pemrosesan stimuli seksual, misalnya nukleus kaudatus, korteks cingulus, insula, girus fusiformis, korteks temporalis, korteks oksipitalis, talamus, amigdala, dan serebelum. Perbedaan aktivasi yang signifikan pada area otak tersebut berperan dalam tingginya akurasi klasifikasi algoritme kami, tetapi hanya ketika diklasifikasikan dengan menggunakan analisis Fisher linear discriminant. Ketika kami merestriksi kalkulasi dari nilai ekspresi individual terhadap area otak tersebut (dengan meningkatkan nilai ambang $t$ ), akurasi klasifikasi rata-rata meningkat dari $89 \%$ menjadi 95\% (Tabel 2).

Tampaknya, algoritme klasifikasi berperan kurang optimal pada kasus-kasus sampel dengan ketertarikan seksual yang masih ambigu. Keseluruhan dari 3 sampel yang salah klasifikasi (Fisher linear discriminant, $t>4$ ) (Tabel 2) merupakan pedofil tipe noneksklusif (2 pedofil heteroseksual dan 1 pedofil homoseksual). Sebagian besar dari pedofil noneksklusif pada sampel kami merupakan heteroseksual (5 dari 7 pedofil noneksklusif). Ini mungkin berperan dalam perbedaan grup yang lebih kecil pada kontras perempuan anak vs dewasa dibandingkan dengan kontras laki-laki anak vs dewasa dan pada misklasifikasi dari 2 pedofil heteroseksual.

Membandingkan klasifikasi pola neurofungsional dengan penilaian phallometric dalam hal akurasi menghasilkan gambaran yang heterogen. Ketika dilakukan pada pedofil yang mengakui orientasi seksualnya, penilaian phallometricd menunjukkan sensitivitas sempurna (100\%), sedangkan klasifikasi berdasarkan fMRI menunjukkan sensitifitas maksimal 92\%. Sebaliknya, spesifisitas klasifikasi berdasarkan fMRI mencapai $100 \%$. Skor spesifisitas pada penilaian phallometric dilaporkan sekitar $81 \%$ ketika pedofil dibandingkan dengan grup kontrol sehat. Totalnya, akurasi klasifikasi rata-rata daripendekatan klasifikasi pola neurofungsional lebih superior dibandingkan dengan penilaian phallometric.

Tetapi, penelitian ini hanya mengikutkan individu yang mengakui secara terbuka bahwa mereka adalah pedofil. Penilaian objektif terhadap ketertarikan seksual secara umum diperlukan ketika terdapat keraguan terhadap ketertarikan seksual dari subjek, sebagai contoh, pada pelaku kekerasan seksual dengan korban tunggal yang menyatakan bukan 
pedofil. Sensitivitas penilaian phallometric pada pedofil yang tidak mengaku dilaporkan sekitar $78 \%$ untuk pedofil heteroseksual dan $89 \%$ untuk pedofil homoseksual. Penurunan sensitivitas $100 \%$ pada pedofil yang mengaku menjadi 78\% dan $89 \%$ pada pedofil yang tidak mengaku dapat disebabkan oleh kemampuan beberapa sampel untuk memanipulasi respon penis mereka selama pemeriksaan phallometric. Saat ini, tidak diketahui apakah sampel dapat memanipulasi respon neurofungsional mereka selama stimuli seksual sejenak selama pemeriksaan MRI.

Temuan kami memunculkan pertanyaan apakah orientasi seksual pada pelaku kekerasan seksual anak harus diperiksa menggunakan fMRI. Beberapa pertimbangan mendukung klasifikasi fMRI otomatis: pertama, klasifikasi otomatis mungkin lebih akurat daripada phallometry; dan kedua, pemeriksaan fMRI kurang intrusif dibandingkan dengan phallometry dan dapat dilakukan pada waktu kurang dari 20 menit. Terlebih, klasifikasi berbasis fMRI mempunyai potensi untuk mengatasi beberapa batasan phallometry lainnya. Penelitian dewasa ini tidak mengikutkan sampel yang tidak dapat diklasifikasn oleh karena responnya yang kurang; sehingga, metode ini mungkin dapat mengatasi masalah ketiadaan respon pada phallometry sirkumferensial. Akhirnya, klasifikasi berbasis fMRI mungkin kurang rentan terhadap manipulasi karena sampel tidak mempunyai waktu untuk memunculkan respon yang disiapkan sebelumnya terhadap beragam stimuli dalam waktu singkat dan saat pemeriksaan fMRI.

Sebagai ringkasan, klasifikasi otomatis dari respon otak fungsional terhadap stimuli seksual adalah teknik untuk menilai orientasi seksual yang menjanjikan pada pelaku kekerasan seksual anak; tetapi, penelitian lebih lanjut diperlukan untuk meningkatkan akurasi klasifikasi, khususnya pada kasus pedofil noneksklusif atau pedofil yang tidak mengaku. Satu kemungkinan mungkin dengan meningkatkan jumlah sampel, mengingat bahwa akurasi Fisher linear discriminant meningkat dengan peningkatan jumlah. Selanjutnya, validitas dari teknik pemeriksaan baru ini harus dites secara lebih luas. Sebagai contoh, reliabilitas tes-retes harus dievaluasi. Masalah ini krusial, dan telah dikritik berulang kali pada phallometry. Terlebih, penelitian di masa depan harus mengikutkan pedofil yang tidak mengakui orientasi seksual mereka. Akhirnya, penelitian fMRI harus mengetes apakah sampel dapat memanipulasi respon mereka terhadap rangsang seksual.

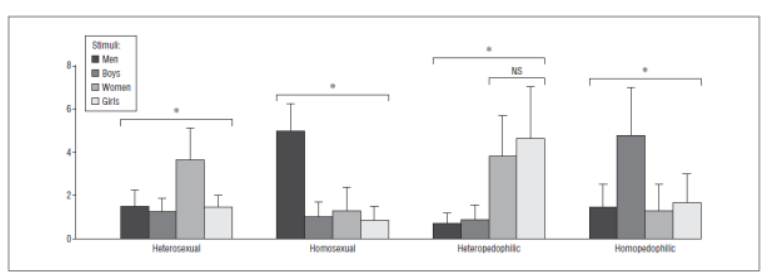

Gambar 1. Rating rata-rata stimuli seksual untuk group sampel heteroseksual, homoseksual, heteropedofilia dan homopedofilia sesuai dengan orientasi seksual yang mereka laporkan sebelumnya. Pedofil nonspesifik terutama heteropedofil. Error bars $=1$ SD. $\quad * P<0.001$. NS menandakan tidak signifikan. 

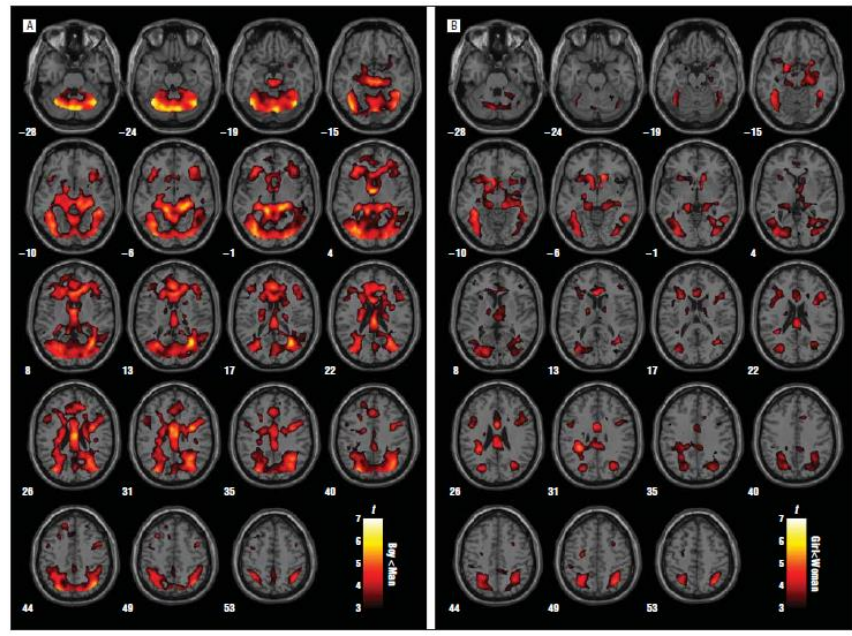

Gambar 2. Perbedaan aktivitas otak antara pedofil dan relawan normal. Statistik aksial peta $t$-score menunjukkan perbedaan antar group pada aktivasi otak fungsional yang dimunculkan oleh gambar anak-anak dan dewasa tanpa busana (dengan nilai ambang pada $\mathrm{P}<0,001$, belum terkoreksi). Peningkatan respon terhadap stimuli anak vs dewasa disajikan pada bagian A untuk stimuli laki-laki dan B stimuli perempuan. Peta $t$-score disajikan di atas foto MRI T1-weighted. Angka-angkanya mewakili koordinat stereotaktik z yang sesuai untuk setiap irisan aksial.

\begin{tabular}{|c|c|c|c|c|c|c|c|}
\hline \multirow[b]{2}{*}{ Brain Area } & \multirow[b]{2}{*}{ Side } & \multirow{2}{*}{$\begin{array}{c}\text { Cluster Size, } \\
\text { Voxels }\end{array}$} & \multirow{2}{*}{$\begin{array}{c}t \text { Value } \\
\text { Maximum }\end{array}$} & \multirow{2}{*}{$\begin{array}{c}z \text { Score } \\
\text { Maximum }\end{array}$} & \multicolumn{3}{|c|}{ MNI Coordinates, mm } \\
\hline & & & & & $x$ & y & $z$ \\
\hline \multicolumn{8}{|c|}{ Pedophiles < controls (boys < men) } \\
\hline Cerebellum & L & 50195 & 6.72 & 6.53 & -38 & -62 & -24 \\
\hline Cerebellum & $\mathrm{R}$ & & 6.36 & 6.19 & 40 & -64 & -22 \\
\hline Lingual gyrus & $\mathrm{L}$ & & 6.05 & 5.91 & -12 & -40 & -2 \\
\hline Anterior thalamus & L & & 6.05 & 5.90 & -2 & -6 & 4 \\
\hline Hippocampus & $\mathrm{R}$ & & 5.99 & 5.85 & 22 & -32 & -4 \\
\hline Occipital lobe & $\ddot{L}$ & & 5.96 & 5.82 & -34 & -76 & 0 \\
\hline Lingual gyrus & $\mathrm{R}$ & & 5.87 & 5.74 & 14 & -34 & 0 \\
\hline Fusiform gyrus & $\mathrm{L}$ & & 5.82 & 5.69 & -38 & -74 & -16 \\
\hline Inferior temporal gyrus & $\mathrm{R}$ & & 5.72 & 5.60 & 46 & -44 & -12 \\
\hline Angular gyrus & $\mathrm{R}$ & & 5.61 & 5.50 & 38 & -66 & 44 \\
\hline \multicolumn{8}{|c|}{ Pedophiles $<$ controls (girls $<$ women) } \\
\hline Nucleus caudate & $\mathrm{R}$ & 17577 & 5.59 & 5.47 & 12 & 18 & -8 \\
\hline Nucleus caudate & $\dddot{L}$ & & 5.27 & 5.18 & -8 & 14 & -8 \\
\hline Superior parietal gyrus & $\mathrm{R}$ & & 5.27 & 5.18 & 32 & -62 & 52 \\
\hline Inferior temporal gyrus & L & & 5.24 & 5.14 & -42 & -44 & -10 \\
\hline Fusiform gyrus & L & & 5.21 & 5.11 & -38 & -46 & -10 \\
\hline Cingulate & L & & 5.07 & 4.98 & -2 & 4 & 28 \\
\hline Occipital lobe & L & & 4.77 & 4.70 & -38 & -78 & 0 \\
\hline Amygdala & L & & 4.75 & 4.68 & -18 & 0 & -12 \\
\hline Superior parietal gyrus & L & & 4.66 & 4.59 & -26 & -56 & 46 \\
\hline Fusiform gyrus & $\mathrm{R}$ & & 4.59 & 4.52 & 44 & -42 & -14 \\
\hline Inferior temporal gyrus & R & & 4.51 & 4.45 & 54 & -56 & -8 \\
\hline $\begin{array}{l}\text { Insula } \\
\text {. }\end{array}$ & $\hat{L}$ & & 4.25 & $\begin{array}{l}4.40 \\
4.19\end{array}$ & -32 & 12 & -10 \\
\hline Inferior frontal gyrus & $\mathrm{R}$ & 623 & 4.21 & 4.16 & 44 & 24 & 22 \\
\hline Thalamus & $\ddot{L}$ & 161 & 4.04 & 4.00 & -16 & -8 & 10 \\
\hline Cerebellum & R & 116 & 3.46 & 3.43 & 28 & -48 & -30 \\
\hline
\end{tabular}

Tabel 1. Pola diskriminatif yang mendasari klasifikasi pedofil vs kelompok kontrol.

Singkatan: MNI, Montreat Neurological Institute

${ }^{a}$ Kluster signifikan saja (nilai ambang tidak terkoreksi: $\mathrm{P}<0,001$ ) 


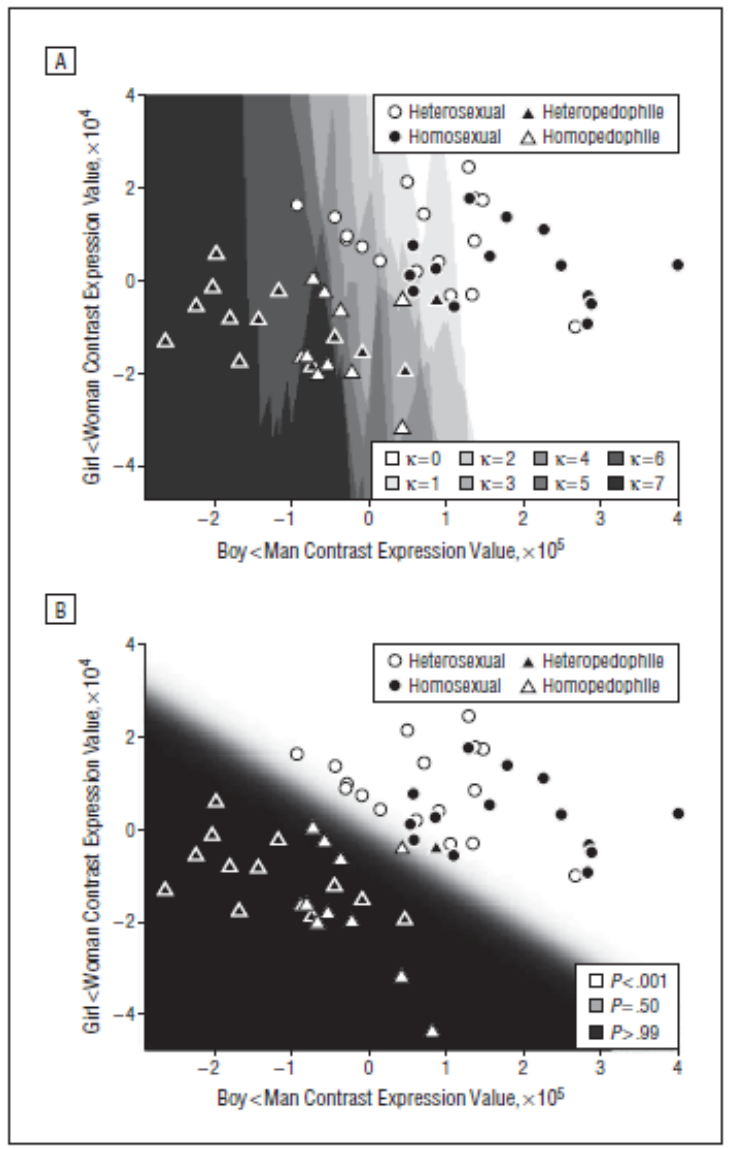

Gambar 3. Klasifikasi pedofil dan kontrol sehat menggunakan nilai ekspresi individu untuk kedua algoritme klasifikasi. A. $\kappa$-Nearest neighbor analysis. Area abu-abu bervariasi sesuai dengan jumlah pedofilik "neighbors". Sampel dengan 3 pedofilik "neighbors" diklasifikasikan sebagai pedofil. B. Fisher linear discriminant analysis.

Sampel dengan $\mathrm{P}_{\text {(pedophilic) }}>0,50$ (area gelap) diklasifikasikan sebagai pedofil.

\begin{tabular}{|c|c|c|c|c|c|c|}
\hline $\begin{array}{l}\text { Classification } \\
\text { Algorithm }\end{array}$ & $\begin{array}{l}\text { Brain Area Considered } \\
\text { for Expression Values }\end{array}$ & $\begin{array}{c}\text { No. of } \\
\text { False Positives }\end{array}$ & Specificity, \% & $\begin{array}{c}\text { No. of } \\
\text { False Negatives }\end{array}$ & Sensitivity, \% & $\begin{array}{c}\text { Mean } \\
\text { Accuracy, \% } \\
\end{array}$ \\
\hline \multicolumn{7}{|l|}{ KNN } \\
\hline & Whole brain & 3 & 91 & 4 & 83 & 88 \\
\hline & $t>2$ & 2 & 94 & 3 & 88 & 91 \\
\hline & $t>3$ & 3 & 91 & 6 & 75 & 84 \\
\hline & $t>4$ & 5 & 84 & 9 & 63 & 75 \\
\hline \multicolumn{7}{|l|}{ Fisher } \\
\hline & Whole brain & 4 & 88 & 2 & 92 & 89 \\
\hline & $t>2$ & 2 & 94 & 2 & 92 & 93 \\
\hline & $t>3$ & 2 & 94 & 3 & 88 & 91 \\
\hline & $t>4$ & 0 & 100 & 3 & 88 & 95 \\
\hline
\end{tabular}

Tabel 2. Skor sensitivitas dan spesifisitas dari Fisher linear discriminant analysis dan $\kappa$-Nearest neighbor analysis setelah validasi silang untuk berbagai level $t$.

aKami mengkalkulasi nilai ekspresi yang dimasukkan ke dalam algoritme klasifikasi dengan menyesuaikan peta $t$ otak keseluruhan atau peta $t$ yang diretriksi dengan nilai ambang $t>2$ sampai $t>4$. 


\section{DAFTAR PUSTAKA}

1. Wetzels P. Pra"valenz und familia "re Hintergru "nde sexuellen Kindesmissbrauchsin Deutschland: Ergebnisse einer repra"sentativen Befragung. Sexuologie. 1997;4(2):89-107.

2. Blanchard R, Klassen P, Dickey R, Kuban ME, Blak T. Sensitivity and specificityof the phallometric test for pedophilia in nonadmitting sex offenders. PsycholAssess. 2001;13(1):118-126.

3. American Psychiatric Association. Diagnostic and Statistical Manual of MentalDisorders. 4th ed, text revision. Washington, DC: American Psychiatric Association; 2000.

4. Blanchard R, Barbaree HE, Bogaert AF, Dickey R, Klassen $\mathrm{P}$, Kuban ME, ZuckerKJ. Fraternal birth order and sexual orientation in pedophiles. Arch Sex Behav.2000;29(5):463-478.

5.SmallboneSW,McCabeBA.Childhoodattachment,ch ildhoodsexualabuse,andonset of masturbation among adult sexual offenders. Sex Abuse. 2003;15(1):1-9.

6. Blanchard R, Kuban ME, Klassen P, Dickey R, Christensen BK, Cantor JM, BlakT. Self-reported head injuries before and after age 13 in pedophilic and nonpedophilic men referred for clinical assessment. Arch Sex Behav. 2003;32(6):573-581.

7. Cantor JM, Blanchard R, Christensen BK, Dickey R, Klassen PE, Beckstead AL,Blak T, Kuban ME. Intelligence, memory, and handedness in pedophilia. Neuropsychology. 2004;18(1):3-14.

8. Schiffer B, Vonlaufen C. Executive dysfunctions in pedophilic and nonpedophilic child molesters. J Sex Med. 2011;8(7):1975-1984.

9. Jespersen $A F$, Lalumière $M L$, Seto $M C$. Sexual abuse history among adult sexoffenders and non-sex offenders: a meta-analysis. Child Abuse Negl. 2009;33(3):179-192.

10. Schiltz K, Witzel J, Northoff G, Zierhut K, Gubka $\mathrm{U}$, Fellmann H, Kaufmann J, Tempelmann C, Wiebking C, Bogerts B. Brain pathology in pedophilic offenders: evidence of volume reduction in the right amygdala and related diencephalic structures. Arch Gen Psychiatry. 2007;64(6):737-746.

11. Schiffer B, Peschel T, Paul T, Gizewski E, Forsting M, Leygraf N, Schedlowski M,Krueger TH. Structural brain abnormalities in the frontostriatal system and cerebellum in pedophilia. J Psychiatr Res. 2007;41(9):753-762.

12. Cantor JM, Kabani N, Christensen BK, Zipursky $\mathrm{RB}$, Barbaree HE, Dickey R, Klassen PE, Mikulis DJ, Kuban ME, Blak T, Richards BA, Hanratty MK, Blanchard R.Cerebral white matter deficiencies in pedophilic men. J Psychiatr Res. 2008;42(3):167-183.

13. Sartorius A, Ruf M, Kief C, Demirakca T, Bailer J, Ende G, Henn FA, MeyerLindenberg A, Dressing $H$. Abnormal amygdala activation profile in pedophilia. Eur Arch Psychiatry Clin Neurosci. 2008;258(5):271277.

14. Walter M, Witzel J, Wiebking C, Gubka U, Rotte M, Schiltz K, Bermpohl F, Tempelmann C, Bogerts B, Heinze HJ, Northoff G. Pedophilia is linked to reducedactivation in hypothalamus and lateral prefrontal cortex during visual eroticstimulation. Biol Psychiatry. 2007;62(6):698-701.

15. Schiffer B, Krueger T, Paul T, de Greiff A, Forsting $M$, Leygraf $N$, Schedlowski $M$, GizewskiE.Brainresponsetovisualsexualstimuliinhom osexualpedophiles.JPsychiatry eurosci. 2008;33(1):23-33.

16. Schiffer B, Paul T, Gizewski E, Forsting M, Leygraf $N$, Schedlowski $M$, KrugerTH. Functional brain correlates of heterosexual paedophilia. Neuroimage. 2008;41(1):80-91.

17. Ponseti J, Granert O, Jansen O, Wolff S, Mehdorn $H$, Bosinski H, Siebner H.Assessment of sexual orientation using the hemodynamic brain response to visual sexual stimuli. J Sex Med. 2009;6(6):16281634.

18. Duchesne S, Caroli A, Geroldi C, Barillot C, Frisoni GB, Collins DL. MRI-basedautomated computer classification of probable $A D$ versus normal controls. IEEETrans Med Imaging. 2008;27(4):509-520.

19. Klo"ppel S, Stonnington CM, Chu C, Draganski B, 
Scahill RI, Rohrer JD, Fox NC,Jack CR Jr, Ashburner J, Frackowiak RS. Automatic classification of MR scans in Alzheimer's disease. Brain. 2008;131(pt 3):681689.

20. Soriano-Mas C, Pujol J, Alonso P, Cardoner N, Mencho'n JM, Harrison BJ, DeusJ, Vallejo J, Gaser C. Identifying patients with obsessive-compulsive disorderusing whole-brain anatomy. Neuroimage. 2007;35(3):1028-1037.

21. Koutsouleris N, Meisenzahl EM, Davatzikos C, Bottlender R, Frodl T, ScheuereckerJ, Schmitt G, Zetzsche T, Decker P, Reiser M, Mo“ller HJ, Gaser C. Use of neuroanatomical pattern classification to identify subjects in at-risk mental states of psychosis and predict disease transition. Arch Gen Psychiatry. 2009;66(7):700-712.

22. $\mathrm{Fu} \mathrm{CH}$, Mourao-Miranda J, Costafreda SG, Khanna A, Marquand AF, WilliamsSC, Brammer MJ. Pattern classification of sad facial processing: toward the development of neurobiological markers in depression. Biol Psychiatry. 2008;63(7):656-662.

23. Hanson RK, Morton-Bourgon KE. The characteristics of persistent sexual offenders: a meta-analysis of recidivism studies. J Consult Clin Psychol. 2005;73(6):1154-1163.

24. Freund K, Watson R. Assessment of the Sensitivity and Specificity of a Phallometric Test: an update of phallometric diagnosis of pedophilia. Psychol Assess.1991;3(2):254-260. doi:10.1037//1040-3590.3.2.254.

25. Howes R. A survey of plethysmographic assessment in North America. Sex Abuse. 1995;7(1):9-24. doi:10.1007/BF02254871.

26. Kuban $M$, Barbaree $H E$, Blanchard R. A comparison of volume and circumference phallometry: response magnitude and method agreement. Arch Sex Behav.1999;28(4):345-359.

27. Kolla NJ, Klassen PE, Kuban ME, Blak T, Blanchard R. Double-blind, placebocontrolled trial of sildenafil in phallometric testing. J Am Acad Psychiatry Law. 2010;38(4):502-511.

28. Dasarathy BV. Nearest Neighbor Norms: NN Pattern Classification Techniques.
Vol 20. Los Alamitos, CA: IEEE Computer Society Press; 1991.

29. Beier KM, Neutze J, Mundt IA, Ahlers CJ, Goecker $D$, Konrad A, Schaefer GA.Encouraging self-identified pedophiles and hebephiles to seek professional help:first results of the Prevention Project Dunkelfeld (PPD). Child Abuse Negl. 2009; 33(8):545-549.

30. Neutze J, Seto MC, Schaefer GA, Mundt IA, Beier KM. Predictors of child pornography offenses and child sexual abuse in a community sample of pedophilesand hebephiles. Sex Abuse. 2011;23(2):212-242.

31. Kirk KM, Bailey JM, Dunne MP, Martin NG. Measurement models for sexual orientation in a community twin sample. Behav Genet. 2000;30(4):345-356.

32. von Aster M, Neubauer A, Horn R. Wechsler Intelligenztest fu"r Erwachsene WIE.Deutschsprachige Bearbeitung und Adaptation des AIS-III von David Wechsler.Frankfurt, Germany: Pearson Assessment; 2006.

33. Lang PJ, Bradley MM, Cuthbert BN. International Affective Picture System (IAPS):Technical Manual and Affective Ratings. Gainesville: The Center for Research inPsychophysiology, University of Florida; 1997.

34. Ponseti J, Bosinski HA, Wolff S, Peller M, Jansen $\mathrm{O}$, Mehdorn HM, Bu“chel C,Siebner HR. A functional endophenotype for sexual orientation in humans. Neuroimage. 2006;33(3):825-833.

35. Bradley MM, Greenwald A, Hamm A. Affective picture processing. In: BirbaumerN, O " hman A, eds. The Structure of Emotion. Go"ttingen, Germany: Hogrefe; 1993:48-65.

36. Friston KJ, Holmes A, Worsley KJ, Poline J, Frith C, Frackowiak RSJ. Statisticalparametric maps in functional imaging: a general linear approach. Hum BrainMapp. 1995;2(4):189210.doi:10.1002/hbm.460020402.

37. Stoleru S, Mouras H. Brain functional imaging studies of sexual desire and arousalin human males. In: Janssen E, ed. The Psychophysiology of Sex. Bloomington:Indiana University Press; 2007:3-34. 
38. Freund K, Blanchard R. Phallometric diagnosis of pedophilia. J Consult Clin Psychol.1989;57(1):100105.
39. Barbaree HE, Baxter DJ, Marshall WL. Brief research report: the reliability of the rape index in a sample of rapists and nonrapists. Violence Vict. 1989;4(4):299-306. 